\title{
Challenges Militating against Primary School Learners' Maximum Access to E-Education Programmes in Goromonzi District of Zimbabwe
}

\author{
Albert Dube*, Professor Borniface Chenjerai Chisaka
}

Zimbabwe

*Corresponding Author: Albert Dube. Zimbabwe

\begin{abstract}
The research study sought to unveil the challenges militating against maximum access to elearning by primary school learners in Goromonzi District of Zimbabwe. E-learning has become the most acceptable mode of pedagogical instruction by most education stakeholders across the globe but its implementation uniformity from state to state is unevenly questionable. The contextual gist of this study rests upon the rationale behind continued shut out of the maximum enjoyment of the e-learning programme by the primary school learners in Goromonzi district of Zimbabwe as compared to their counterparts in other countries. The existed e-learning implementation mis-norma among e-learners from different countries posed a need for an investigative study.

The study adopted pragmatism as a research philosophy informing the pursued mixed method paradigm that combined both qualitative and quantitative approaches in a triangular form. The population of the study was composed of teachers, school heads and schools inspectors of the Goromonzi district of Mashonaland east province in Zimbabwe. The sample of six primary schools with an average of twenty-five participants each were purposively selected. The researcher used in-depth interviews, questionnaires, document analysis, focus group discussions and observation to collect and generate the requisite data.

The study found out that the Zimbabwe government and its Primary and Secondary Education Ministry`s attempt to resource the schools with computers through the Presidential computerisation scheme did not benefit all schools, hence the national e-learning programme implementation was thwarted on resource inadequacy reasons. It also was found out that the Zimbabwe e-learning programme suffered poor implementation timing since the Ministry of Primary and Secondary Education adopted the e-learning programme into the schools before all schools were computerised with technological infrastructural devises equipment. The government did not also in-service all its active teachers in the main stream in I.C.T domain resulting in some teachers having no confidence in using technology to carry out an e-lesson. Most of the Heads of schools were techno-phobia, hence their confidence to carry out an e-lessons supervision was compromised and their administrative e-service contrived as well. It also was discovered that most of the key active e-learning teachers in Goromonzi district were female teachers than the male ones, defying a plethora of research findings purporting that technology is a world of males.

The implications drawn from the study include the need for the government of Zimbabwe through its Primary and Secondary Education Ministry to seek donations globally, continentally or nationally in order to provide e-Learning resources the e-learning programme that has been adopted and proved worthy pursuing in the Zimbabwe education system. The core-relations between the adopted e-learning as a teaching method and the traditional teaching method was not comparatively adequately investigated in this study hence further study in this regard recommended.
\end{abstract}

\section{INTRODUCTION}

This e-learning research study focused on unveiling challenges faced by primary schools in Goromonzi District of Zimbabwe in an effort try and maximise the benefits of primary schools elearning programme to improve the future of learners. The rationale behind the study put in question form is that; why do learners in primary schools of Goromonzi District remain shut out in the enjoyment of e-learning programme as compared to their counterparts in other countries. The challenges of e-learning exposure deficiencies or e-learning experiences under-utilisation by Goromonzi District primary school learners was the causal reason of this investigative study. The investigational study on the e-learning exposure challenges in Goromonzi District was done in primary schools found in Goromonzi district of Zimbabwe which is a rural area set up environment. 


\section{BACKground to THE Problem}

The research study looked at the e-learning programme implementation challenges militating against maximum access to e-learning programme by primary school learners in Goromonzi District primary schools. The research study attempted to take a funnel approach where the background to the problem looked at a global perspective going to continental aspect then to the Zimbabwe e-learning situation as the nation where the research study was carried out. The e-learning implementation challenges in the Goromonzi District of Zimbabwe as evidenced by the collected data and data generation processes, were comparatively juxtaposed to the global and continental obtained information related to the background to the problem section of the study. Even though some countries were doing well in implementing e-learning other countries were struggling a thing which propelled the researcher to embark on this type of research study.

Looking at the Zimbabwean background to the problem of this study which was premised on the understanding that e-learning the world over has gradually replaced the teacher-chalk board traditional method of learning with the use of computer and interactive boards aided learning being mostly accepted by the young learners who are captivated by its (e-learning) aliveness in the learning experiences the study unveiled some vicarious e-learning challenges in Zimbabwe.

Since the mid-1980s the rapid evolution of Computer Assisted Learning (CAL) and ComputerAssisted Instruction (CAI) into Course Management Systems (CMS) and Virtual Learning Environments (VLEs) has been evidenced (Kozma 2005). Zimbabwe as a country took off in elearning in primary schools a little bit later. The e-learning programme was first launched in Zimbabwe Government Primary schools at Chogugudza Primary School in Goromonzi District, Mashonaland East Province, on the $28^{\text {th }}$ of March 2012 by the then President of the Republic of Zimbabwe, R.G.Mugabe (Herald Newspaper, 28 March 2012). Regardless of this initiative, primary school learners in Goromonzi Education District are still facing difficulties in e-learning exposure barely nine years after the launch.

The e-learning programme in Zimbabwe uses among other things, the digital content learning software which is approved by the Zimbabwe Schools Examination Council (ZIMSEC) and the Curriculum Development Unit (CDU). The approved digital learning content is distributed and produced by a company known as E-learning Solutions Private Company which was established in the year 2000 and has offices in South Africa and Zimbabwe. This e-learning company has an ecosystem of partners that plan,

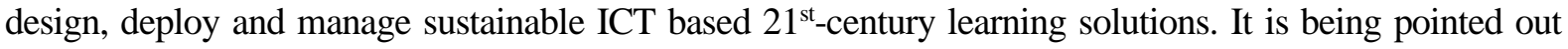
that the E-learning Solutions Company supports over 1000 primary and secondary schools across SADC and COMESA. (E-learning Solutions Private Limited website: http://www.elearning.co.zw).

The study therefore aimed at finding the implementation challenges militating against the e-learning programme in primary schools of Zimbabwe and attempt to suggest ways of addressing the challenges so that the learners in Goromonzi and elsewhere can maximize all the benefits associated with pedagogical education e-learning programme.

\section{PuRpose OF THE STUdy}

The purpose of this study was to find out the underlying challenges militating against e-learning programme implementing in the Goromonzi District of Zimbabwe. The possible solutions to the challenges were also purposefully sought to be used as remedy to the challenges.

\subsection{Research Questions}

From an investigative perspective, this study sought to answer the following questions:

\section{The primary question was:}

- Are the primary school learners fully benefiting from the e-learning programme in Goromonzi District?

\section{The subsidiary questions were:}

- What are the challenges dwindling the implementation progress of the e-learning programme in Gromonzi District. 
- To what extent do primary schools acquire the e-learning programme supporting hardware and software infrastructure for the benefit of the learners?

- In what way has the legal framework of the e-learning policy document facilitated the maximisation of the e-learning benefits by primary school learners?

- What is the impact of the challenges to the maximum accession of the e-learning programme and how can all primary school learners be made to access e-learning?

- How best can authorities be made to focus on making e-learning accessible to all primary school learners?

- To what extend does the technological e-learning mode of delivery compare and contrast itself to the traditional "teacher-telling" mode of instruction.

\section{MethodologY}

The study perused the mixed method research method and academically adopted the pragmatism research philosophy which was used to collect and generate the requisite data from the field. Qualitative research method component of the mixed method has been considered useful in this study because it recognises, in concurrence with Leedy and Ormrod (2013), that the issues being studied are multidimensional and layered. The multidimensionality of issues need to be revealed in their multifaceted and dense form to obtain unquestionable validity of the study. In addition, the basic premise on which this study is based is that reality is constructed by thee-teachers interacting within their social-technological world. The qualitative research component of the chosen mixed method approach is interested in understanding the meaning researchers have constructed, how they make sense of their techno-world and the experiences they have in the general world. The e-teachers' realities would be varied which should lead to an examination of the complexity of holistic eeducation views rather than just narrowing meanings into a few categories or ideas.

The desire to pursue pragmatism philosophical approach propped up due to the need to evaluate the elearning theories or beliefs in terms of their success or failure on practical application in the eeducation systems. Apart from perusing pragmatism approach the study also followed the critical theory model of the paradigm and the concurrent triangulation research design which effectively addressed the e-learning research problem and constituted the collection, measurement, analysis and generation of data. It is only within this methodological perspective framework that this study was framed and hatched. The end resultant outcome of the methodological pattern strategy findings is found in the research study findings and recommendations section.

\subsection{Research Paradigm}

This e-learning research study was based on realism. Realism refers to the theory that whatever knowledge we acquire through the senses is a true reflection of what happens, Barker (1991). In this research study, believing in our senses as the source of the truth means that all data that was gathered from respondents in Goromonzi education district through questionnaires, interviews as well as observation through the sense of sight were a true reflection of the truth. The term paradigm according to Barker (2003) is referred to as a design that is utilized in the collection and interpretation of data. The study is framed within the interpretive perspective as asserted by Bitzer (2015). The interpretive paradigm was selected for it links to the purpose of the research study. Elisha (2012) defines the research paradigms as the actions guided by a set of basic belief. The same sentiments are shared by Creswell (2009). The interpretive perspective matches the purpose of the study and it is the most appropriate research paradigm for it the researcher with an in-depth understanding of the experiences of the participants of the study. The approach also provides the researcher with an insider's perspective resulting in the credibility and trustworthiness of the obtained data.

\subsection{Population of the Study}

In the study, the population refers to the aggregation of respondents who meet the designated set of criteria as purported by Bums and Groove (2003). The individuals who are the focus of the study are therefore referred to as the population.Target Population. It is in Goromonzi district that the primary schools national e-learning centre was launched in the year 2012 at Chogugudza Primary School. The 
National e-learning centre was launched at Chogugudza Primary, a school which belongs to the Goromonzi district andmore schools from Chinamora zone participated in this research study since they are more rural and the national e-learning centre was launched in that zone. The selected seven primary schools were being managed by substantive school heads and were implementing the elearning programme. The population in this study constituted of the primary school heads, teachers and a few education inspectors from Goromonzi District of Mashonaland East Province in Zimbabwe.

\subsection{Research Approach}

This research study has adopted the mixed method approach. The concept of mixing different methods of research studies strategies originated in 1959 when Campbell and Fisk used multimethods to study validity of psychological traits (Creswell, 2009). They later encouraged other researchers to employ their multi-method matrix to examine multiple approaches to data collection and generation (Mason 2002 and Chisaka 2014). This prompted other researchers to mix methods and soon the approaches associated with field methods such as observations and interviews were combined with traditional surveys quantitative data; Sieber, (1973). Therefore using the mixed methods strategy ensures that quantitative and qualitative data can be combined and merged into one large database or the results used side by side to reinforce each other, Creswell and Clark, (2007). There are three general strategies namely sequential mixed methods, concurrent mixed methods and transformative mixed methods. According to Creswell (2009) concurrent mixed methods procedures are those in which the researcher converges or merges quantitative and qualitative data in order to provide a comprehensive analysis of the research problem. In this design approach the investigator collected both forms of data at the same time and then integrated the consolidated information in the interpretation of the overall results. Again in the same study design, the researcher strategically embedded one smaller form of data within another larger data collection in order to analyse different types of questions where the qualitative study aspect addressed the process while the quantitative study approach addressed the research study outcomes.

This research study had a unique approach in that it combined a quantitative strategy (survey research) with qualitative strategy (case study) in the data collection process stage. The adopted mixed methods approach entailed in this study a deliberate mix of different data collection methods with the sole objective which was of ensuring that all the key issues that the research questions sought to address were dealt with adequately since e-learning was a practical, complex and new subject in the education system. The choice of the mixed method approach was necessitated by the nature of the elearning technology data which the researcher intended to gather from the collected data.

\subsection{Research Design}

Research study design means the description of the format and theoretical structure for the actual implementation of the research investigation. Saunders et al (2007) pointed out that research design spells out the basic strategies that the researcher adopts to develop information that is accurate and interpretable during the research process. The term research design is actually synonymous with the term research plan. If the research design a plan, it is very necessary therefore to include this section of the research as well as to ensure that the plan is well organized and that it is properly implemented. The research study process made sure that the sample of the respondents was representative in all aspects. Babbie (1979) averred that representativeness is the quality of a sample of having the same distribution of characteristics as the population from which the sample was collected.

Every research methodology is underpinned by three approach pillars which are the research philosophy, the research paradigm and the research design. The research design of this study was used as the framework of the research method and the case study technique was chosen by the researcher to hone in the suitable e-learning subject matter in order to bring acceptable research study results.

The e-education research study presented the case study in Goromonzi district as the method of the research and defined the research method as a plan or course of action employed to guide data collection, generation, analysis and interpretation into findings. The researcher concurred very well with Tellis (1997) that a case study was a strategy for data generation, its analysis and interpretation in an in-depth manner and this suited it very well for this research study. The study also sought to establish the extent to which six institutions of primary education learning practised e-learning 
education to achieve quality primary education. The exploratory research approach was considered because of its usefulness and appropriateness for a research study that addressed a subject matter about which little was known, like the e-education technological subject being studied in a rural area environment targeting primary school learners. There was generally very little information about the existence of e-education programme implementation underlying challenges. The researcher's goal in adopting the exploratory research was supported by Nurmiet.al (2001) who pointed out that there was a need to produce possible insights through exhibiting some familiarities with basic detail, settings and concerns of e-education in a well-grounded picture of the education system being developed and the generation of new technological ideas and assumptions.

The researcher also agreed with UNESCO (2002) that a real life situation, such as rural primary schools e-education, was complex and was not easily determined. However, the supporting statement which came from Sarah (2005) who pointed out that an exploratory case study was employed when an institution or programme was so new that little information existed, outside the institution, regarding the workings and impact of the institution or programme. The researcher had little information about primary school learners e-learning experiences but the fact that implementation of the e-learning programme in primary schools had commenced in Zimbabwe schools came handy.

\subsection{Data Collection Methods/Procedures}

Data collection was done using questionnaires randomly. This means that both male and female teachers were included in the questionnaires. This increased the chances of obtaining data which is free from bias throughout the whole district of Goromonzi. The interview technique of data collection was also used in this study.

\subsection{The interview}

This data collection technique involves the oral questioning of respondents, either as individuals or as a group. The interviews were conducted in a form of individual interviews and were guided by openended questions. The standardized open-ended questions interview was extremely structured in terms of the wording of the questions. This open-endedness allowed the participants to contribute as much detailed information as they desired and it also allowed the researcher to ask probing questions as a means of follow-up. Standardized open-ended interviews are likely the most popular form of interviewing utilized in research studies because of the nature of the open-ended questions, allowing the participants to fully express their viewpoints and experiences. Participants were asked identical questions, but the questions were also worded so that responses were open-ended.

\subsection{Observation}

The researcher also utilized the observation method during data collection. This meant that the researcher from time to time observed the feelings of participants through observing facial expressions among other non-verbal expressions. This was possible because some of the questionnaires were distributed physically, allowing the researcher to have a face to face interaction with respondents, whilst observing social distancing. Observation is vital in data collection since it allows the researcher to see if there is congruence between what respondents say and what they portray.

\section{Data Analysis}

Data collected through questionnaires and interviews from schools were then put together, sorted out and logically presented through the use of tables, graphs and pie charts. This three way presentation of data was done to cater for all people who could want to refer to this research project in future. The use of tables was chosen for its ability to presents data orderly in a simple way.

Graphs were used because they give a quick understanding of data if one is conversant with their use. Graphs also make use of a small space on data presentation. Graphs are however partially challenging to construct but the researcher made thorough researches on their use to address this challenge.

Pie charts were also used to present the data. The use of pie chart was done to embrace the uniqueness of various people who might refer to this piece of work in the comprehension of various forms of data. 
Analysis of data was done basing on age, sex and work experiences. These grouping were done in order to convey meaning of the data to its recipients. Each reader will refer to the method of data presentation that one is more comfortable with. There is however no one way of data presentation that is better than the other but choice depends on an individual's perception and mastery, hence the inclusion of the all the three methods.

\subsection{Analysis of Questionnaire Data}

Content analysis was used to analyse data collected through interviews using interview guide for key informants. This was done by editing, coding classification and tabulation of the collected data so as to change into qualitative. The qualitative data from teachers and heads was analysed using tables, graphs and pie charts.

\subsection{Processing of Data}

Data was collected from respondents and tabulated on tables. The data was later processed to construct graphs as well as pie charts. This was done to make it easy to compute the data. Processing of data was done both manually and electronically. The reason for processing data and presenting it in different forms was to make it easy for various readers of this piece of writing to understand it since people are unique in the way they master concepts. This was also done to save apace. Non-readers can also easily grasp concepts presented in form of graphs and pie charts without taking too much time.

\section{RESUlts}

\subsection{Background Information of the Participants and Institutions}

A brief account of the participants was given in this section of the research study. The names of the participants and the names of the institutions were changed to protect their identity in accordance with ethical and legal dictates considerations and respect of the provision of confidentiality adopted by the researcher (See § 3.7.6,). The institutions which were primary schools were given pseudonyms. The participants were given alphanumerical names; for instance, the first participant at Goromonzi District (GD) was named GD1. The names of all the other participants followed the same pattern; the contribution of each participant was referenced with the line number from the transcript of the primary school under investigation. The six primary school institutions were located in Goromonzi District of Mashonaland East Province. The use of pseudonyms enabled the researcher to engage in a transparent and fair discussion of the data from the participants and that of their primary schools unencumbered by personal bias. The participants engaged in the study on the understanding of anonymity and confidentiality. That understanding was upheld in the discussion.

The participants were divided into three broad areas: senior management, which comprised the District Schools Inspectors and the schools inspectorate bench, Heads of schools and their Deputies and Primary School Teachers. The profile of each key informant participant was shown in the table below. The purpose of the profiles was to demonstrate the depth of academic and professional qualifications, knowledge and experience resident in the key informant participants. In terms of numbers, the School Inspectors were 4, The Heads of schools were 6, The Deputy Heads of Schools were 6 and the Primary school Teachers were 105 making a total of 120 participants.

\section{The Participants' Response Rate}

\begin{tabular}{|l|l|l|l|}
\hline $\begin{array}{c}\text { E-learning Schools Served with } \\
\text { Instruments }\end{array}$ & $\begin{array}{c}\text { Distributed } \\
\text { Instruments }\end{array}$ & $\begin{array}{c}\text { Returned } \\
\text { Instruments }\end{array}$ & Response Rate \\
\hline 1 & 20 & 13 & $65 \%$ \\
\hline 2 & 20 & 17 & $85 \%$ \\
\hline 3 & 20 & 18 & $90 \%$ \\
\hline 4 & 20 & 12 & $60 \%$ \\
\hline 5 & 20 & 13 & $65 \%$ \\
\hline 6 & 20 & 17 & $85 \%$ \\
\hline 7 & 20 & 15 & $75 \%$ \\
\hline Total & 140 & 105 & $100 \%$ \\
\hline
\end{tabular}

The table above shows that out of the 140 questionnaire papers distributed to teachers only 105 papers were returned. The findings were drawn from the 105 papers retrieved from the participants. 


\subsection{The Actual Research Findings}

The study found out some findings related to the biographical details. The study found out that most of the teachers had a Diploma in education while a few of the teachers had acquired degrees relevant to their profession. Most Heads of schools had degrees while Schools Inspectors had Masters Degrees in Education. In terms of I.C.T qualifications, diplomas and degrees in I.C.T were only found in Teachers and not Heads and Inspectors of schools. This shows that a new generation crop which is I.C.T compliant is emerging in the Zimbabwe education sector. One can learn that the notion that women are a neglected group when it comes to the e-educational roles did not ensue in this study considering the discovery by this research study that there were more female teachers than their male counterparts. Observational, interviews and focused group discussions results revealed that some of these young female teachers have acquired degrees in I.C.T and are very active in and outside the class. They were e-learning self-motivated even though resource scarcity affected their great elearning aspirations. The findings reveal that most teachers involved in e-learning were still young and active. Most of the teachers were between 30-40 years of age. This group is the ground floor implementers of the e-learning for they are contact persons with learners. The study found out that elearning is for the energetic ones. It was also found out that most school heads and schools Inspectors were within the 50-60 years age range. It was also discovered that this age group struggled with technological compatibility. They were not active at all regarding manipulation of the computer devices.

There were also findings related to institutional e-learning implementation challenges. The sampled schools had substantive school heads that were qualified to administrate education institutions like schools. The schools had teachers qualified to teach primary school learners. In terms of teaching the I.C.T as a subject, very few teachers were qualified. This gap resulted in many teachers who had no hands-on experience in I.C.T skills preferring to teach using traditional teaching methods than the elearning method. The research study also found out that schools had not established proper e-learning computer laboratories. It was also found out that what were computer laboratories in most schools were mere classrooms except at Chogugudza primary school and Zimbiru Primary School were properly secured computer laboratories were established. Most schools kept the few available computers in the Head's office and carried the few computers to the room they called the laboratory when learners wanted to use them. So many learners were using one computer resulting in less interactive manipulation of the computer by learners. The research also found out that most schools had no electricity back-up yet. At the time of the research Zimbabwe as a country was going through electricity load shedding of almost 18 hours of no power per day while power could be accessed for only 6 hours during the night per day. Only schools with generators could make it given such a circumstance. No school was connected to solar power. Schools as institutions of learning had no enough computers for the learners rendering e-learning programme implementation almost impossible. There were no school heads who were trained to administer e-learning programmes in schools and that is the reason why the e-learning area was the most challenging area for the school heads where the heads were not at liberty to supervise and lead by example. There was no internet supply in most schools except Zimbiru Primary School and Chogugudza Primary School. Internet enhances the e-learning programme hence its absence in the school thwarted the proper implementation of the e-learning programme in the schools. The studies also found out that schools also experienced some damages to the e-learning infrastructural equipment caused by learners, computer viruses and natural disasters. Almost every year during the rainy season lightning would strike the computer laboratories and damage computers. The schools incurred some repairing expenses yearly due to damages. Some schools had preventative measures to safeguard damages like installing anti-virus software and lightning arresters. Most schools had no implementable e-learning timetable routinely being followed for the benefit of learners due to lack of resources and knowledge of the programme. However, some had properly laid down operating e-learning time tables. Some schools had no operating school rules on the e-learning programme. Teachers and learners were not guided on what to do regarding e-learning programme implementation. Some schools, however, had e-learning operating rules stuck in the computer laboratories. Some schools had no computers in the school head's office for typing and printing the reports related to the school head's duties. Some heads preferred to give school clerks the computer and constantly asked the clerks to type their handwritten reports on their behalf thereby leaving them with minimal hands-on computer skills practice. All in all 
the research study found out that schools were not capacitated to implement the e-learning programme even though the Zimbabwe government adopted the e-learning programme into its education system. The zeal and eagerness to implement were very noticeable in both teachers and learners; however, the implementing challenges overtook the existing implementing interest in teachers and learners.

On ministerial e-learning implementation capability the study found out that the government of Zimbabwe's attempt to resource schools with computers through the Presidential computerisation scheme did not benefit all schools. A total of only 3 primary schools in Goromonzi District about 90 schools countrywide benefited from the presidential computerisation programme which was just a drop in the ocean. The study also found out that the Ministry of Primary and Secondary Education adopted the e-learning programme into schools before all schools were computer equipped. This situation caused the irregularities in terms of the degree of e-learning implementation in schools. In schools where resources were donated by the Presidential computerisation programme, there is a significant level of implementation while in schools that did not receive the donation the implementation dexterity level is low. The research discovered that the act of donating computers to some schools and failure to do the same to other schools by the Zimbabwean government through its presidential office was received with mixed feelings in other schools. Observation by this study might not be wrong to rule out that some schools used the uneven selective donation of computers in schools as a scapegoat for poor e-learning programme implementation. However, in some schools that did not receive the computers' donation but were headed by young school heads who are technology compliant like Zimbiru Primary, the e-learning programme was being implemented very well using available school resources. The study also found out that the government did not train all its current active teachers in line with the e-learning implementation programme in schools. To the teachers who were stationed in schools that received computer donations, the government staff developed them for a few days on how to use the computers. Some teachers were still struggling with e-learning operating dynamics even though they went through the staff development sessions. The research also discovered that even though I.C.T skills are being taught in teachers colleges, the new teachers who were being deployed into schools from colleges could not practice skills acquired from the colleges in schools unless they were deployed in schools with elearning resources and activities. The Zimbabwe government needs to address the disparities which exist in teachers regarding e-learning knowledge and skills acquisition. It was also found out that the government and its Education Ministry did not engage the first world countries or the business world companies local or abroad to fund the e-learning programme in schools.

\section{CONCLUSION}

The results of the gathered data show that regardless of the implementation challenges a dynamic eeducation programme has a place that benefits learners in primary education.

From the review of related literature perspective, this thesis has defined e-learning as a hybrid term made up of two parts which are e + learning which brings up the term e-learning. The "e" of the elearning is key in the identification of the digitalism of this learning method. In simple terms, elearning has been defined as the learning that utilises electronic technologies to access educational curriculum outside the traditional classroom.

The research study employed different methodological approaches that were commensurate with the chosen mixed-method research approach. The critical theory paradigm was applied alongside the pragmatism philosophical approach. The thesis also adopted the concurrent triangulation research design which became ideal in the analysis of the investigation results.

This study has reasonably proved that e-learning knows no territorial boundaries if adopted. It is a programme that is implementable in towns and rural areas and compatible with both the young and the old. It is a very flexible teaching method approach that needs support especially during this new curriculum era where subjects have been made to be skills-based and have been made many subjects not easy to be taught by a single teacher in the primary education sector. The E-learning programme is the solution to the multiplicity of the learning areas propounded by the emergence of the new curriculum than the traditional learning methods.

The study has also discovered that most of the teaching methodology practices that have proved to have a lot of weaknesses when used in traditional teaching methods like mixed ability grouping 
approach to teaching, child to child interaction approach to teaching and the teacher-centered lecture method to teaching have solutions to their weaknesses in the e-learning teaching method approach.

It was noted that regardless of how professional the education administrators can be, without financial, human or material resources, no miracles can emerge in terms of dealing with the discovered e-learning dynamic challenges negating the positive exposure by primary school learners in Goromonzi District of Zimbabwe.

Some conclusions were derived from the findings on e-learning practices in primary schools which include the implementation of e-learning in primary schools which was marred by non-uniformity as evidenced by variations in terms of how e-learning programme was being implemented in primary schools. This was influenced partly by the absence of primary schools e-learning policy by the Ministry of Primary and Secondary Education. This affected the implementation of e-learning as there was no accountability and clear monitoring procedures in primary schools of Goromonzi district. The general conclusive understanding of what e-learning entailed in primary schools helped in proclaiming positive perceptions toward e-learning in primary schools. As a result of clear enrolment procedures, students with technological interest were more in primary schools than those without, thereby making e-learning programme inevitable in primary schools. Due to the rigid curriculum in primary schools in Zimbabwe, students with technological interest were not adequately resourced in terms of possession of technological gadgets thereby affecting the implementation of e-learning programme. The e-learning programme in primary schools was affected by traditional instructional methods which were used by teachers and the same assessment methodological procedures were not very appropriate to other learners with special needs unlike e-learning computer based assessment. It is paramount to note that despite strides by primary school leaders to accommodate e-learning programme in schools the available physical environment and the infrastructure was not accessible by all learners including learners with special needs. Due to lack of resources, implementation of elearning in Goromonzi primary schools continue to be restricted to unlinked computer gadgets. The absence of the primary schools e-learning Education implementing policy from the Ministry of Primary and Secondary Education affected the implementation of e-learning in Goromonzi primary schools of Zimbabwe. As a result of rigid curriculum, primary schools were not able to adequately accommodate diversity and this affected the implementation of e-learning programme in Goromonzi District of Zimbabwe. The hierarchical structure of the Ministry of Primary and Secondary Education might have paved way for top-down approach which posed as a challenge in implementing e-learning education in Goromonzi District of Zimbabwe. The implementation of e-learning education programme in primary schools was affected by lack of financial support from the Ministry of Primary and Secondary Education and the Government to support the acquisition of relevant resources and technological devices. Shortage of financial, material, infrastructure and human resources greatly affected the implementation of e-learning programme in primary schools of Goromonzi District of Zimbabwe. As such, primary schools in Goromonzi District had failed to establish e-learning resource centres. The partially accessible physical environment primary schools resulted in failing to accommodate all learners thus affecting the implementation of e-learning Education. In addition, the hostile social environment affected inclusive e-learning practices to some extent in Goromonzi District primary schools. As a result of negative perceptions by administrators that perceived enrolment of SWDs as a waste of resources, there were few students with disabilities in Teachers Colleges in Zimbabwe. The work overload by teachers in primary schools impedes the implementation of e-learning education programme to the extent that there was no time to attend to individual needs of learners. Lack of information by e-learning leaner's on their rights and services that they could get made e-learners susceptible and less empowered. Failure to use Sign Language by primary school teachers and other learners presented communication barriers for learners with hearing impairment in primary schools in Goromonzi District. Learners with hearing impairment were the most affected in Goromonzi primary schools when they faced communication barriers. Hence, elearners with hearing impairment were placed and not adequately included. Provision of adequate resources in terms of computers, books, digital software, technological devices and furniture enhanced the implementation of e-learning programme. Involvement of stakeholders was significant in the implementation of e-learning programme. Primary schools staff members in Goromonzi District of Zimbabwe required adequate and constant training on e-learning education so that they understood diversity and improve on their performance. Established e-learning programme teams in primary 
schools might help in co-ordination of primary schools e-learning education programmes. Awareness campaigns on e-learning education were important in reaching primary schools, as well as, the community at large. Conducive physical and social environment were central to effective e-learning education in Goromonzi District. Change of attitudes by implementers and stakeholders was central in ensuring effectiveness of e-learning education programme in primary schools of Goromonzi District of Zimbabwe. Both the Heads of schools and teachers should have positive attitudes towards including e-learning in their schools. A national and ministerial policy on e-learning education was imperative as derived from international states and frameworks. An inclusive curriculum which was based on practical experience was central in implementing e-learning education. The traditional teaching methods and the assessment criteria should be inclusive so as to cater for diversity among learners.

\section{RECOMMENDATIONS}

This section of the e-learning study was based on recommendations that were derived from the findings and conclusions of the study. The Ministry of Primary and Secondary Education should ensure that there was some level of standardisation in the way primary schools implements e-learning education. This could be done through an established national policy or guidelines. Primary school administrators should have clear enrolment procedures to ensure there is increase proportional representation of learners with special needs in primary schools of Goromonzi District of Zimbabwe. They should establish a quota system when enrolling learners with disabilities. The school heads should ensure that enrolment adverts encourage learners with disabilities to apply. School teachers and administrators should offer practical approach to Inclusive e-learning education which includes practical skills and in inclusive e-school. The Ministry of Primary and Secondary Education should revise the curriculum so that it becomes flexible in terms of e-learning subjects offered, timetable and assessment so as to meet diverse needs of e-learners. Primary school learners should adopt interactive and collaborator methods of instruction as well as adapting assessment criteria that meet the needs of all e-learners. Primary school administrators should improve on infrastructure adjustments so as to make its accessible by all learners which should be monitored by Ministry of Primary and Secondary Education. Ministry of Primary and Secondary Education and primary school administrators should embark on various avenues and projects as well as network with Non-Governmental Organisations so that they avail resources that are necessary for e-learning education to be successful. Primary school administrators should provide adequate support to e-learning education programmes through provision of adequate resources and technological assistive e-devices. The Ministry of Primary and Secondary education should provide opportunities for workshops and staff development programmes for primary school teachers and administrators so as to equip them with relevant skills and attitudes towards e-learning education programme. These could be done on rotational basis to ensure that all primary schools are equipped with e-learning educational skills and attitudes. Primary school administrators should ensure that mission statements, visions and values for the schools are aligned to their perceptions on e-learning programmes in primary schools. The Ministry of Primary and secondary education, through various departments, must conscientise communities so that they develop positive perceptions towards e-learning education. The Ministry of Primary and Secondary Education and school administrators should have a budget to support e-learning in primary schools. They could liaise with NGOs and other organisations that could assist them with various resources. Primary schools can introduce an e-learning levy to help in funding e-learning in the institutions. The Ministry of Primary and Secondary Education should have a flexible structure to accommodate ideas from the implementers of the e-learning programme in primary schools. Primary School administrators and teachers should speed up the process of establishing e-learning resource centres so that they support e-learning education programmes. The Ministry of Primary and Secondary Education should employ more teachers so that teachers are not overburden by many duties and to reduce the teacher-learner ratio. This would enable teacher to give individual attention to learners. Primary Schools should provide practical training to school personnel in Sign Language and Braille so that they are able to accommodate with those learners with hearing and visual impairment respectively for enhancing inclusive e-education. The Ministry of Primary and Secondary Education and primary schools should adopt a multidisciplinary approach where various primary education stakeholders (NGOs, parents, churches, Government, and political groups) were involved in the implementation of e-learning programme in primary schools. Primary schools could include inclusive 
e-education in their strategic planning for effective implementation and monitoring of e-learning in primary schools. Primary schools should network among themselves and interact so that they learn from each other on how best to implement e-learning programme in primary schools. The Ministry of Primary and Secondary Education should set up e-learning programme teams to co-ordinate elearning education programmes in primary schools. Each primary school administrator should set up e-learning department which becomes the central point of implementation process.

\section{REFERENCES}

[1] Agboola A.K (2006), "Assessing the awareness and perceptions of academic staffs in using e-learning tool for instructional delivery in a postsecondary institution: a case study," The Innovation Journal: The Public Sector Innovation Journal, vol. 11 no. 3, article 4.

[2] Alexander, O. (2003). ICT in developing Countries, A Cross-Sectorial Snapshot. HEC, University of Lausanne.An African perspective. Kenwyn; Juta.

[3] Aydin,C.H and Tasci.D(2014), "Measuring readiness for e-learning: reflections from an emerging country," Educational Technology and Society, vol. 8 no. 4.

[4] Babbie, E. (2004). The Practice of Social Research. New York, WadsworthPublishingCompany .

[5] Babbie, E. Mouton, J. Vorster and Prozesky, B. (2003).The Practice of Social Research. Oxford:Oxford University Press.

[6] Bauer, M. (2000). Classic Content Analysis: a Review. In: M. Bauer and G. Gaskell, (eds): Qualitative Researching with Text, Image and Sound. Sage Publications Inc, London.

[7] Becker, T. and Meyers, P. (1974). Empathy and Bravado: Interviewing Reluctant Bureaucrats.Public Opinion Quarterly, 38, pp.605-613.

[8] Becta (2003). A review of the research literature on the use of Managed learning environments and virtual learning Environments in education, and a consideration of the Implications for schools in the United Kingdom.

[9] Berenfeld, B. (1999). The internet in our classroom: Teaching tomorrows skills for tomorrow's world. In Sylvia A. Ware(ed). Science and Environment Education Views from Developing Countries (pp 215-234). Washington, DC: The World Bank.

[10] Berenson, M.L and Levine, D. (1986) Basic Business Statistics; Concepts and application; Third Edition; Prentice-Hall International Editions (pp36- 75).

[11]Berg, B. (1995). Qualitative Research Methods for the Social Sciences. New York, Allyn\& Bacon.

[12] Black, T. (2003). The e-business handbook; the 2003 review of innovation at

[13] Blaikie, N. (1993). Approaches to Social Enquiry. Polity Press in association with Blackwell Publishers Ltd, Cambridge.

[14] Bless, C and Higson-Smith C. (1995). Fundamentals of social research methods:

[15] Bradshaw P. (2006). ICT Strategy for Schools and Learners: Liverpool City Council Children's Services. Retrieved 19 August 2007: Available online: http:// www.liverpool.gov.uk/image .

[16]Charmaz, K. (2003). Qualitative Interviewing and Grounded Theory Analysis. In: J. Holstein and J. Gubrium, (eds). Inside Interviewing, New Lenses, New Concerns. Sage Publications Inc, California.

[17] Cheng.K (2006), A Research Study on Students' Level of Acceptance in Applying E-Learning for Business Courses - A Case Study on a Technical College in Taiwan.

[18] Cherryholmes, C.H. (1992, August - September). Notes on Pragmatism and Scientific Realism. Educational Researcher, 13-17.

[19]El-Seoud. S (2013), “The Effect of E-learning on Learner's Motivation: A Case Study on Evaluating ELearning and its Effect on Egyptian Higher Education", The International Conference on E-Learningin the Workplace (ICELW 2013), New York, NY, USA.

[20]Evoh, C.J (2007). ICTs, Primary Education, and the Knowledge Economy: Exploring the Roles of the Private Sectors in Post- Apartheid South Africa. The New School University, USA.

[21]Fageeh. A.I (2011), "EFL students' readiness for e-learning: factors influencing e-learners acceptance of the Blackboard in a Saudi university," Jalt Call Journal, vol. 7 no. 1. 
[22]FeeK.H(2005), Delivering E-Learning: A Complete Strategy for Design Application and Assessment, London and Philadelphea:Kogan.

[23] FitzPatrick (2012), "Key Success Factors of eLearning in Education: A Professional development Model to Evaluate and Support eLearning", US-China Education Review, British University in Egypt, http://www.bue.edu.eg. Retrieved on 20/11/2019.

[24] Fjelstad, O. and Semboja, J. (1998). Why people pay taxes. The case study of the Development levy in Tanzana, CMI Working paper5:1998. Bergen. Chr, Michelsen institute.

[25]Fleming, S. (2002). Information and Communication Technologies (ICTs) and friendly ICT", African Telecom Summit, Accra, Ghana.

[26] Franks, T. (1999) Capacity Building and Institutional Development: Reflections on Water, Public Administration and Development, volume 19, 51-62.

[27] Gall M.D. (1996) Education Research, An Introduction, 6th Ed New York, Longman Publishers.

[28] Gaskell, G. (2000). Individual and Group Interviewing. In: M. Bauer and G. Gaskell, (eds).Qualitative Researching with Text, Image and Sound. London, Sage Publications Inc,pp.38-56.

[29] Gillies J.A., (2003). IT-Supported Learning Strategies, The Value of Online Student

[30] Gitman, L. 1. (2009). Principles of managerial finance: New York, Pearson Education Limited.

[31] Goode, R. (1984) Government Finance in Developing Countries. New Delhi; Tata McGraw Hill.

Citation: Albert Dube, Professor Borniface Chenjerai Chisaka (2021). "Challenges Militating against Primary School Learners' Maximum Access to E-Education Programmes in Goromonzi District of Zimbabwe", International Journal of Research Studies in Computer Science and Engineering (IJRSCSE), 8(1), pp.31-42. DOI: http://dx.doi.org/10.20431/2349-4859.0801004

Copyright: (C) 2021 Authors, This is an open-access article distributed under the terms of the Creative Commons Attribution License, which permits unrestricted use, distribution, and reproduction in any medium, provided the original author and source are credited. 